\title{
THE EFFECT OF OBJECTIONS TO TREATY RESERVATIONS
}

A state desiring to become a party to a multilateral agreement, ${ }^{1}$ but unwilling to subscribe to all its terms, will often qualify its acceptance with a reservation. $^{2}$ If another party to the agreement objects to the reservation, the agreement is inoperative between the reserving and objecting states. ${ }^{3}$ It is not

1. The word "agreement" embraces a host of instruments variously described as conventions, protocols, arrangements, accords, acts, declarations, modi vivendi, statutes, pacts, covenants and executive agreements. "The international juridical effect of a treaty is not dependent upon the name given to the instrument." Art. 4, Harvard Research Draft Convention on the Law of Treaties, 29 Am. J. INT'L L. Supp. 657, 710 (1935). (Hereinafter cited as HaRvard RESEARCH). But the name given an instrument may have significance for internal purposes: for example, "treaties" become binding upon the United States only with the consent of two-thirds of the Senate, while "executive agreements" may be brought into force by the signature of the President. For an attempt to distinguish between treaties and executive agreements according to their content, see Fraser, Treaties and Executive Agreements, SEN. Doc. No. 244, 78th Cong., 2d Sess. (1944). For the view that treaties and executive agreements differ only in the procedure required for their adoption, see McDougal \& Lans, Treaties and Congressional-Executive or Presidential Agreements: Interchangeable Instruments of National Policy: 1, 54 YaLE L. J. 181 (1945).

2. A reservation is any formal, written declaration relating to the terms of the agreement, made by one of the states before its final acceptance and communicated to the other interested states. Miller, Reservations to Treatres 76 (1919). A reservation to be effective must be made by the appropriate authority for making the original agreement binding. Thus, in the United States a reservation must be made by the President with the advice and consent of two-thirds of the Senate, or by the President with the approval of a majority resolution of both houses of Congress, or in some instances by the President alone. Also the reservation should be inscribed upon the treaty or on an instrument collateral to the agreement, such as the instrument of ratification, accession, or signature. HaRVARD RESEARCH 847-53.

Article 13 of the HARVARD RESEARCH limits the use of the term "reservation" to those declarations which "limit the effect of treaty" as it applies to the reserving state. This definition is used in order to exclude from "reservation" those declarations which seek to "amend" the treaty or merely state an interpretation or "understanding" which the declarant has of the treaty. $I d$. at 857 . This definition seems too narrow; for, by complying with the formalities described above, states may incorporate any terms they can agree upon into declarations made after the conclusion of negotiations. It seems unnecessary to apply more than one label to these declarations since they all have the same legal effect. For this reason, "reservation" is best used to include any declaration which has been made with the formalities required to make the agreement effective.

3. 5 Hackworth, Digest of International Law 104 (1943); Harvard Research 870. A reservation may be analogized to a new offer in a contract which must be accepted to make the contract binding. When a reservation is accepted by the other parties, it becomes "as binding and obligatory as if it were inserted in the body of the instrument." Doe et al. v. Braden, 16 How. 635, 656 (U.S. 1853).

Although the original agreement is never binding on any state without its express consent, acceptance of reservations may be implied. A state accepting an agreement is held to have accepted all reservations made prior to its acceptance. And a state is bound by any reservation made subsequent to its acceptance unless it expressly objects to the 
certain, however, whether a state, by objecting to a reservation, can thereby bar the reserving state from becoming a party to the agreement with states willing to accept the reservation. Nor is it certain whether a state which has merely signed the agreement has the same power in this regard as a state which has taken the further step of becoming a party. ${ }^{4}$

The Genocide Convention ${ }^{5}$ brought these two closely related questions before the United Nations for the first time when several parties objected to the reservations made by other states in accepting the Convention. ${ }^{b}$ The General Assembly submitted to the International Court of Justice and the International Law Commission the two questions of the effect to be given objections by parties and objections by states not yet parties. ${ }^{7}$ The Assembly

reservation. HaRvard Research 901; Owen, Reservations to Multilateral Treaties, 38 Y ALE L.J. 1086, 1113 (1929).

4. Only a party is bound by the terms of the agreement. See note 26 infra. A state may become a party to a multilateral agreement by ratification, accession, or signature. Ratification is the final pronouncement by which a state approves the action taken by its negotiators. By accession, states which did not participate in negotiation of the agreement may subsequently announce their willingness to be bound by its terms. Some agreements may be brought into force by the signature of the chief executive or his representative. See, generally, 1 Hudson, Internationat LegisLation \$\$21-3 (1931) ; 5 Hackworte, Digest OF INTERNATIONAL LAW 48-84 (1943); HARVARD RESEARCH 787-843.

5. This Convention makes any attempt to destroy a racial, national, or ethnic group a crime under international law. See, generally, International Convention on the Prevention and Punishment of the Crime of Genocide, SEN. Doc. EXEc. O, 81st Cong., 1st Sess. 2-6 (1949), and Comment, 58 YALE L.J. 1142 (1949).

The United States, as of April 1, 1951, had not ratified the Convention. On April 12, 1950, a subcommittee of the Senate Foreign Relations Committee recommended that the United States ratify with reservations expressly limiting the definition of Genocide to those acts which would cause "permanent physical injury" to a "substantial portion" of any national, ethnical, racial, or religious group. The purpose of these reservations was to insure that segregation laws would not be construed as constituting genocide. For the full text of the proposed United States reservations see N.Y. Times, April 13, 1950, p. 5 , col. 1 .

6. As of March 9, 1951, Bulgaria, Romania, Poland, Czechoslovakia and the Philippines had qualified their final acceptance of the Convention with reservations. Australia, Cambodia, Ceylon, Ecuador, El Salvador, France, Guatemala and Viet-Nam had objected to some or all of the reservations. Communication to the YALE LAw Journal from the United Nations Legal Department, March 9, 1951, in Yale Law Library. Bulgaria, Romania, Poland and Czechoslovakia attached identical reservations. One reservation sought to avoid reference of disputes to the International Court of Justice without the unanimous approval of the parties to the dispute. The other provided that the terms of the Convention should extend to non-self-governing territories under the trusteeship of parties to the agreement. The government of the Philippines attached a reservation that would guarantee certain Philippine public officials the same immunity from prosecution under the Convention that they have under Philippine constitutional law. For the text of the reservations, see Reservations to Multilateral Conventions, U.N. Doc. A/1372 (Report of the Secretary-General) Annex I $\llbracket 4,16$ (Sept. 20, 1950). (Hereinafter cited as SECRETARY-GENERAL's REPORT.)

7. At the present time no state which is not a party has made any objections to the reservations which have been made to the Genocide Convention. The question of the effect 
will use the recommendations of these bodies in formulating general rules to apply to agreements concluded under the auspices of the United Nations. ${ }^{8}$

The questions presented by the Assembly resolution require analysis of the function of reservations. Reservations enable a state to subscribe to the general principles of an agreement without sacrificing particular policies which it considers vital to its interests. ${ }^{9}$ In a constitutional democracy, reservations are often necessary to secure the support of an agreement by domestic groups. ${ }^{10}$

of such an objection was, however, discussed in the Committee debates. Official Records of the U. N. General Assembly (5th Sess.) U.N. Doc. A/C.6/SR.217 (Oct. 5, 1950).

The International Court of Justice was requested to give an advisory opinion and the International Law Commission was invited to study both questions and report its conclusions to the General Assembly. Resolution of the General Assembly 478 (2), U.N. Doc. A/1517, adopted by the General Assembly, on recommendation of its Sixth (Legal) Committee, Nov. 16, 1950.

These questions were first presented to the General Assembly by the SECRETARY General's Report. The General Assembly in turn referred them to its Sixth (Legal) Committee where they were considered in detail. In Committee debates delegates of the United Kingdom and other Western European nations argued that no reserving state be allowed to become a party to a multilateral agreement unless its reservation was unanimously accepted by all the signatories, whether or not the signatories had ratified the agreement. Delegates from the United States and other Western Hemisphere countries, with the exception of Brazil, urged that an objection should only make the agreement inoperative between the objecting and reserving state. Summary reports of the committee debates may be found in the Official Records of the U.N. General Assembly (5th Sess.) U.N. Doc. A/C.6/SR.217-25 (Oct. 5-20, 1950). See also 9 U.N. Burc. 477 (1950).

8. These rules can be binding only as to those agreements in which the SecretaryGeneral is designated as depositary. The depositary function of the Secretary-General includes receiving ratifications and accessions to the agreement, notifying other states of these acceptances, and declaring the agreement in force at the proper time. See SECRETARY-GENERAL's REPORT IIT 1-3. This function of the Secretary-General is to be distinguished from his duty under Article 102 of the United Nations Charter to register and publish all international agreements.

9. The United States has accepted many agreements with reservations embodying the principles of the Monroe Doctrine. See, e.g., the U. S. reservations to the Hague Conventions of 1899, 1907, MIILER, op. cit. supra. note 2, at 135, 144.

10. See, e.g., the reservations which the United States government was forced to make in order to get Senate approval of the Statute for the Permanent Court of International Justice. Wright, The United States and the Permanent Court of International Justice, 21 Ax. J. INT'L. I. 1, 7 (1927),

In the United States there are many who argue that the Tenth Amendment to the Constitution, which reserves certain powers to the states, imposes a substantive limitation on the treaty-making power of the federal government in addition to the procedural limitation imposed by the requirement that the ratification of treaties must be approved by the Senate. Tucker, Limitatrons on the Treaty-Making Power (1915). But for the view that the only substantive limitations on the treaty-making power are "practical" and "political", see Magnusson, Our Membership in the United Nations and the Federal Treaty Power under the Constitution, 34 VA. I. R. 137, 160-4 (1948).

The constitutional requirement in many countries that treaties must be acceptable to the legislative branch of the government has forced the negotiators of agreements to be much more responsive to popular pressures than they were when national repre- 
They may also be used to incorporate into the agreement provisions which a state was unable to persuade the majority to accept at the time of negotiation. ${ }^{11}$ Reservations thus enable states to enter into agreements even though all parties cannot agree in every detail.

A recent report by the Secretary-General concludes that states whose reservations are not accepted unanimously must be excluded from agreements reached under United Nations auspices. ${ }^{12}$ This conclusion is based on what the report describes as the "law-making" character of such agreements. Under a law-making agreement the parties adopt rules of law to be enforced by the government of each party. ${ }^{13}$ The obligations of the parties must be uniform for equitable and efficient enforcement of such an agreement. The only return which a state receives for accepting the full obligations of a law-making agreement, the report emphasized, is assurance that all other parties will do likewise, and thus, by adopting uniform laws, enhance the peace and general welfare of the international community. ${ }^{14} \mathrm{~A}$ state binding itself to all the terms of an agreement is not receiving what it bargained for unless it can exclude those states making objectionable reservations.

This argument does not stand up. States must be assumed to join an agreement in order to promote the principles set forth by that agreement. ${ }^{15}$ Maxi-

sentatives had full power to bind their governments. See Nicorson, Diplomacy 86-9 (1939).

11. See, e.g., the attempt of Bulgaria to extend the provisions of the Genocide Convention to non-self-governing territories. Note 6, supra. A similar proposal was defeated at the negotiation of the Convention. Official Records of the U.N. General Assembly (5th Sess.) U.N. Doc. A/C.6/SR.223, p. 68 (Oct. 16, 1950). See also the attempt of the German delegates on signing the Convention for the Suppression of White Slave Traffic, Paris, 1910, to make a reservation which embodied essentially the same provisions as a proposal which had been put forth and rejected during the negotiation of the agreement. Malkin, Reservations to Multilateral Conventions, 7 BRTT. Y.B. INT'L L. 141, 151 (1926).

12. SeCretary-Generax’s Report, Annex II, $\llbracket 15$.

International organizations, charged with the duty of receiving acceptances to multilateral agreements, have handled this problem in two ways. Under the procedure followed by the Organization of American States, a state making a reservation may enter into the agreement with any state willing to accept the reservation. See the statement of Mr. Jimenez de Arechaga (Uruguay) before the Sixth (Legal) Committee of the General Assembly where he argued in support of this practice. Official Records of the U.N. General Assembly (5th Sess.) U.N. Doc. A/C.6/SR. 217, p.33. (Oct. 5, 1950). Under the procedure followed by the League of Nations, a reserving state could not become a party to an agreement if there was objection to its reservation. 8 League of Nations Offictal Journal 800, 881 (1927). The Harvard Researce regards the practice of the League to be correct under international law. $I d$. at 870 . For a detailed analysis of the operation of these two systems, see Sanders, Reservations to Multilateral Treaties Made in the Act of Ratification or Adherence, 33 Axr. J. INT'L L. 488 (1939).

13. Secretary-General's Report $\Uparrow 32$.

14. Id. at $\llbracket 35$. This argument is also advanced by the HARVARD Researce 871.

15. The SECRETARY-GENERAL's REPORT points out that "[A] state willing to become a party must be assumed to wish to enforce at least the core of the agreement." Id. at $\llbracket 34$. 
mum participation in the agreement, not mere uniformity of obligation, will best promote those principles. Moreover, world cooperation will be speeded more rapidly by encouraging agreement on general principles if not on specific details. ${ }^{16}$ To permit multilateral agreements only among those states which see eye to eye on all terms will reduce the area of common action. ${ }^{17}$ Even where the reservation would substantially lessen the obligation of the reserving state, it will generally be more desirable to have the limited cooperation of that state than to exclude it altogether. ${ }^{18}$ States will inevitably seek to protect what they conceive to be their particular interests; unless they are permitted to do this by reservations, it is doubtful that they will be willing to enter into international agreements. ${ }^{10}$

16. It is generally recognized that agreements which formulate rules of law are valuable instruments in creating a world community because they mobilize public opinion to the support of their announced principles. See McDougal, The Role of Law in World Politics, 20 Miss. L.J. 253, 260 (1949). It is better to have some instruments for international cooperation even though they are imperfect than, by insisting on agreements which establish uniform obligations, to have no agreement at all. See, e.g., Schachter, Book Review, 60 Y ALE L. J. 189 (1951): "[M]any of us are grateful that we have at least an imperfect instrument [the United Nations Charter] for world order and, more important, that this instrument is being construed not in terms of its deficiencies but in order to make effective its principles and purposes." Id. at 193. This statement was made in answer to KelSEN, LAw of THE UNited NATions (1950), which suggests that the United Nations Charter is ineffective because it is not a logically consistent and coherent legal document.

17. In practice, reservations frequently do not change materially the obligations of the reserving state. The United States reservation to the International Sanitary Convention, Paris, 1903, for example, provided that persons should be held under "observation" rather than "surveillance" to determine whether they had the plague. 2 Malioy, Treaties, Conventions, International Acts, Protocols, and Agreeaments Between the United States and Other Powers, 1776-1909, p. 2129. (1910). It would certainly be a harsh rule which allowed a state to exclude the United States from that Convention because of such a minor reservation.

18. The reservations made by Bulgaria, Poland, Romania and Czechoslovakia to the Genocide Convention would substantially change their obligations under the Convention. See note 6 supra. Under their first reservation, no state could bring charges that one of the reserving states had violated the Convention before the International Court of Justice without the consent of that state. This is almost the only sanction which can presently be applied against a state which violates the Convention. Nevertheless, it seems more desirable to have those states subscribing to the principle that genocide is a crime under international law than it would be to exclude them from all participation in the Convention.

A similar example is the British reservation to the International Sanitary Convention, Paris, 1903, which provided that Britain had certain rights to renounce the Convention. 2 Malrox, op. cit. supra note 17, at 2127. Although this appears to be a substantial reservation, the operation of the Convention would have been more seriously impaired by the exclusion of an important maritime power like Great Britain than by permitting it to participate on those terms.

19. It might be argued that states faced with the possibility of total exclusion from international agreements would avoid making reservations. If this assumption were correct, the rule proposed by the SECRETARY-GENERAL's REPORT would have the salutary 
But where an agreement would become unworkable or highly inequitable if a reserving state were permitted to become a party over the objection of another party, an objection should bar the reserving state from membership. An agreement setting up an international organization would become unworkable if, for example, the parties disagreed on salaries, terms of office, or voting procedures. ${ }^{20}$ An agreement would become inequitable if a state were permitted to become a party with a reservation capable of depriving the objecting states of all the benefits they expected to receive from the agreement. No state, for example, should be permitted to become a party to the proposed agreement for international control of atomic energy while maintaining a reservation, over the objection of others, which exempts that state from international inspection of its atomic energy installations.

No individual state, however, should be permitted to determine whether a reservation falls within the "unworkable" or "inequitable" category. ${ }^{21}$ The Secretary-General assumes that states will object only to those reservations which subvert the "basic purposes" of the agreement."22 Experience with the Genocide Convention has proved this to be incorrect. Several states have objected to reservations which do not seem to impugn the "essence of the convention."'23 The International Court of Justice, rather than the individual states, should decide what effect the reservation would have upon the agreement. In each case the Secretary-General should ask the Court whether the reservation in question would make the agreement unworkable or highly inequitable. Only if the Court decides that the reservation would have one

effect of promoting greater uniformity in international agreements without a loss of participation. Such an argument, however, fails to take into account that reservations may express vital national policies which states will not sacrifice at any cost.

20. See, e.g., the Cuban reservation to the Protocol for the Revision of the Statute of the Permanent Court of International Justice, 1929, which sought to change the salaries and terms of office of the judges. 1 Hudson, International Legislation 582 (1931); Hudson, The Cuban Reservations and the Revision of the Statute of the Permanent Court of International Justice, 26 AM. J. INT'L L. 590, 591 (1932). The Court could not have functioned unless consent were unanimous on such matters; Cuba should not have been allowed to become a party unless its reservation were accepted unanimously. Cuba withdrew this reservation after objection from a substantial number of parties. Id. at 593.

21. There is nothing to prevent a state from frivolously excluding a state, no matter how inconsequential its reservation may be, if each party is given the power to exclude a reserving state by objecting to its reservation. Allowing a state to become a party to an agreement while maintaining a reservation to which there has been objection would not open the door for frivolous reservations. The reserving state could not become a party to an agreement vis-à-vis an objecting state. See note 3 supra. This factor both restrains the use of reservations and forces the reserving state to attenuate its reservations.

22. Secretary-Generai's Report $\llbracket 34$.

23. Ioid. The reservation which seeks to extend the terms of the Convention to include trust areas is not contrary to the purpose of the Convention. See note 6 supra. 
of these effects should an objection exclude the reserving state from the agreement. $^{24}$

The adoption of this procedure would also make it possible to decide whether an objection by a state which has only signed the agreement should have the same effect as an objection by a party. ${ }^{25}$ This issue will arise only where the reservation would make the agreement unworkable or highly inequitable since even a party's objection will not bar membership in other cases. While a state which has only signed an agreement is not bound by $\mathrm{it}^{26}$ a signatory may have as much interest in preserving the integrity of the agreement as a state already a party. In many instances, especially in constitutional democracies, a government cannot give its final consent without substantial delay. But in order to prevent abusive use of objections by signatories who do not become parties, ${ }^{27}$ an objection by a signatory should bar the reserving

24. The proposed plan could be put into effect by resolution of the General Assembly. At present the Assembly has the power to refer questions to the International Court of Justice for an advisory opinion. United Nations Charter, Article 96. Under this power the Assembly could instruct the Secretary-General to submit any reservation to which there has been objection to the Court with the request that it decide whether the reservation would make the agreement unworkable or highly inequitable. The Assembly resolution could further instruct the Secretary-General to be bound by the decision of the International Court.

The International Court of Justice would be the appropriate body to decide this question. Another possibility might be to set up a new agency to perform this function. The Court, however, is an existing institution whose opinions would probably have more weight than those of a new agency. It is an international organization established to apply objective standards without regard to national interests. It is not at present overworked; nor would referring these questions to the Court materially increase its work. The Genocide Convention is the first agreement concluded under the auspices of the United Nations that has been accepted with reservations which met with objections.

Since the question of whether the reservation would make the agreement unworkable or highly inequitable, could ordinarily be decided without taking evidence, it could be decided without substantial delay. Advisory opinons are generally rendered by the Court within four or five months after being presented to the court. INTERNATroNal CoURT of JUSTICE YeArBook 1949-50, 53-62 (1950). Further, Article 82 of the rules of the Court provides that where necessary the court may take "necessary steps to accelerate the procedure." Charter of the United Nations, Statute and Rules of Court 82 (2d ed. 1947). The procedure might be accelerated by having the question of whether the reservation would make the agreement unworkable or highly inequitable decided before the Chamber for Summary Procedure under Article 72 of the Rules of Court. Id. at 79.

25. The Harvard RESEARCH takes the position that a signatory may exclude the reserving state from the agreement by objecting to the reservation. Id. at 870 . The Secretary-General of the United Nations reports, on the other hand, that only a party is allowed to exclude a reserving state from participation in an agreement. SECRETARY GENERAL's REPORT $\Uparrow 44$.

26. Iloilo Claims, United States-Great Britain, Claims Arbitration, 1925 (Reprinted in Briggs, The LAw of Natrons 424 (1938)). The terms of the agreement may, however, expressly provide that it shall take effect upon signature. Art. 9, Harvard RESEARCH 778.

27. A state which signs an agreement is under no obligation to ratify it. 1 Hudson, INTERAATIONAL LegrsLation $\$ 18$ (1931). See also Harley, The Obligation to Ratify Treaties, 13 AM. J. INT'L L. 389, 404 (1919). 
state for only a limited period after the objection is registered. If within that period the signatory does not itself become a party, the reserving state should be allowed to enter the agreement. ${ }^{28}$

International cooperation will be advanced by policies which foster maximum participation in multilateral agreements. A reserving state should not be excluded from an agreement because of objection to its reservation unless the reservation would make the agreement unworkable or highly inequitable. The International Court of Justice-not an individual stateshould decide whether the reservation in question would have this effect.

The practice of signing agreements, but failing to ratify them, is very common. On Sept. 31, 1931, 58 agreements had been concluded under the auspices of the League of Nations; 739 ratifications had been deposited, but 825 signatures remained unratified. League of Nations Document A. 26.1931 v., p. 9.

28. An examination of the procedure for ratifying treaties in the leading states of the world indicates that six months would probably be sufficient time for any state to give its final acceptance to an agreement provided that its legislative body is in session at some time during that period. Camara, THE Ramification of International TrEaties 94-117 (1949). The period might be extended until the International Court of Justice gives its opinion if this takes longer than six months after the objection is made. For a detailed exposition of the procedure for ratifying agreements in effect in fifty leading nations in 1933, see Arnold, Treaty-Making Procedure (1933). 